\title{
Process Optimization for Enhanced Biogas Production from Mango Pulp Waste
}

\author{
C. Gopinathan ${ }^{1}$, A. T. Vivek ${ }^{2}$ \\ ${ }^{1,2}$ Bioprocess laboratory, Department of Biotechnology, University of Calicut, Tenjhipalam, P.O. -673635,Kerala, India
}

\begin{abstract}
India is the largest producer and consumer of fruit and vegetable waste in the world. India produces annually, 18 million tonnes of mangos out of which $30 \%$ goes as waste due to improper storage, transportation lack of appropriate post harvest technologies and damage caused due to pests and diseases. As part of mango processing in the food industry, huge quantities of mango pulp is produced which can be used as a high quality substrate for biogas production. Since mango pulp is a high carbon substrate, supplementation of urea has proved to improve biogas production. Similarly, various metal ions have stimulatory effects in enhancing the biogas production from raw mango pulp waste especially $\mathrm{Fe}^{2+}$. Also, optimum combinations of various metal ions further boost the biogas production.
\end{abstract}

Keywords: Anaerobic digestion, Biogas production, Mango pulp waste, urea, and metal ions.

\section{Introduction}

India has got huge potential for utilization of renewable bioresources, which can be converted, into bioenergy. The fossil fuels are short in supply and the demand increasing rapidly [1]. Anaerobic digestion is used for energy recovery from agricultural products and agro-industrial wastes. The products of such anaerobic digestion are mixtures of different gases mainly of methane and carbon dioxide potentially used for heat and power generation [2-5]. Also, the sludge residue is used as a soil alternative or as starting material for compost generation [6-7]. Since the digestate contains different amounts of unconverted organic matter, it could be used for energy production after drying treatment. Of the fruit wastes produced, only $0.5 \%$ is utilized for conversion to useful products and anaerobic treatment of agricultural is better option for profitable utilization of such wastes [8].

Mango (Mangifera indica L.) is a fruit grown in tropical regions and is cultivated on an area of approximately 3.7 million ha worldwide. It is the second highest tropical fruit in terms of production globally. India is the largest producer of mangoes accounting 18 million tonnes annually that is $42 \%$ of the total global production [9]. It is rich in micronutrients, vitamins and other phytochemicals [10]. From the residual composition of mango pulp, it is very evident that it is rich in carbon than nitrogen. Since these substrates lead to acidification inside bioreactor creating imbalance of $\mathrm{pH}$ (below 6.5), it leads to inhibition of methanogenic processes. Such problems can be tackled by minimizing the process of acidification with right mix of waste to reduce waste containing high simple sugars [11-12].

Supplementation of cheap nitrogenous substrates will give stability leading to continuity of the process. Similarly, various metal ions have profound effect in enhancing methanogenic activity. The concentration of the metal ions should be optimized to improve the rate of biogas production from agro-waste [13]. The agro-wastes such as mango pulp, which is available in huge amounts in India, has tremendous potential to be used in biogas production technology, reducing pollution as well as fostering economic growth.

Therefore, the present study was carried out to optimize biogas production from mango pulp waste and also, to optimize the concentration of nitrogeneous substrates and metal ions in order to boost the biogas production. Quantification of methane content from the biogas produced was done as part of this research.

\section{Materials and Methods}

The feedstock consisted of rotten/raw mango pulp waste collected from Palayam market, Kozhikode in Kerala, India. These mango wastes were handpicked and transported to laboratory in polyethylene bags and was stored in $4^{\circ} \mathrm{C}$. An anaerobic digester of total volume of $750 \mathrm{~mL}$ was set-up. Fresh cow dung was used as inoculum and fermentation mixture was poured into $750 \mathrm{~mL}$ conical flask enclosed with one holed rubber stopper. This conical flask was connected to another inverted $750 \mathrm{~mL}$ conical flask connected through rubber tubing filled completely with water completely and closed using two holed rubber stopper. The fermentation gases produced were collected in the inverted conical flask and an equal volume of water displaced is collected in another $750 \mathrm{~mL}$ flask. The daily-displaced water was accurately measured using measuring cylinder that is equal to the amount of biogas produced in a day for the respective experimental set-up.

\subsection{Biomethanation of mango pulp waste}

To determine the biogas production with raw mango pulp as substrate, the experiment was set-up as in Table1.

\subsection{Biomethanation of $\mathrm{pH}$ adjusted mango pulp waste}

The fermentation reaction mixture containing mango pulp waste was prepared by adjusting $\mathrm{pH}$ using $1 \mathrm{~N} \mathrm{NaOH}$ and the experiment was setup as given in Table. 2 


\section{International Journal of Science and Research (IJSR) \\ ISSN (Online): 2319-7064}

Index Copernicus Value (2013): 6.14 | Impact Factor (2015): 6.391

\subsection{Biomethanation of mango pulp waste with varying concentrations of urea supplementation}

In order to find out optimal concentration of urea for biogas production, five individual reactions were prepared with varying concentrations of urea as given Table.3.

\subsection{Impact of metal ions on Biomethanation of mango pulp waste}

Four independent reaction mixtures were set-up to study the influence of metal ions on the reaction mixture as given in Table.4.In all of these cases, $3 \%$ Urea was mixed.

\subsection{Biomethanation of mango pulp waste with different combinations and concentrations of metal ions}

To optimize the combination and the concentration of metal ions, the fermentation reaction mixtures were fed as given in Table.5.

\subsection{Biomethanation of mango pulp waste under optimized conditions and quantification of methane}

The amount of $\mathrm{CH}_{4}$ from the total biogas produced was measured by $5 \% \mathrm{NaOH}$ scrubbing method. Positive and negative control was setup as given in Table.6.

\section{Results and Discussion}

Fig.1 shows the biomethanation of mango pulp waste where biogas produced in a period of 10 days was quantitated with respect to control. Raw mango pulp produced $4.3 \mathrm{~L}$ of biogas when compared to control $(0.33 \mathrm{~L})$. This proves that raw mango pulp can be directly used as a substrate for effective biogas production.Fig. 2 shows the biomethanation of $\mathrm{pH}$ adjusted mango pulp. Mango pulp is acidic in nature and methanogens are sensitive to such low $\mathrm{pH}$. Hence, the raw mango pulp was adjusted to $\mathrm{pH}$ of 7.0 and used for biomethanation process. The cumulative biogas production increased to $10.38 \mathrm{~L}$ compared to control, proving that $\mathrm{pH}$ adjustment boosts the biogas production.Fig. 3 shows the biomethanation of mango pulp waste with varying concentrations of urea since mango pulp is a carbon rich substrate. In this context, the experimentation with urea ranging from $1 \%-7 \%$ shows that $3 \%$ concentration of urea gives the maximum output of $9.2 \mathrm{~L}$ in a period of 10 days. Urea is a cheap nitrogenous raw material that does not add to the overall production cost. Hence, urea can be used as an additive for large-scale production of biogas from mango pulp waste.

Fig.4 shows the biomethanation data of mango pulp waste in the presence of various metal ions. These have got profound effect in activating biomethanogenic pathway. Some of them play major role as cofactor for efficient functioning of various enzymes involved in methanogenic pathway. From fig.4, it is very evident that $\mathrm{Fe}^{2+}$ has more stimulatory effect than $\mathrm{Mg}^{2+}, \mathrm{Cu}^{2+}$ and $\mathrm{Zn}^{2+}$. Fig.5 shows the biomethanation data of mango pulp waste under different combinations and concentrations of metal ions. The unique combination of $3 \%$ urea, 25ppm $\mathrm{FeCl}_{2}, 25 \mathrm{ppm} \mathrm{CaCl}_{2}$ and $25 \mathrm{ppm} \mathrm{MgCl}_{2}$ had the maximum biogas yield (15.2L) compared to control. This data presents the economically viability of this bioprocess towards scale-up. Fig.6 shows the methane output data from mango pulp waste under optimized conditions with respect to control. Methane produced was $8.512 \mathrm{~L}$ in 10 days under optimized conditions. The percentage of methane was more than $50 \%$ under optimized conditions as well as in positive control, which is a positive factor for this type of bioprocess projects.

Table 1: Composition of fermentation mixture for biomethanation of mango pulp waste

\begin{tabular}{|c|c|}
\hline Experimental set-up & Fermentation mixture \\
\hline Control & $17.5 \mathrm{~g}$ cow dung $+682.5 \mathrm{~mL}$ water \\
\hline Raw mango pulp & $\begin{array}{c}17.5 \mathrm{~g} \text { cow dung }+332.5 \mathrm{~mL} \text { mango } \\
\text { pulp }+350 \mathrm{~mL} \text { water }\end{array}$ \\
\hline
\end{tabular}

Table 2: Composition of fermentation mixture for biomethanation of $\mathrm{pH}$ adjusted mango pulp waste

\begin{tabular}{|c|c|}
\hline Experimental set-up & Fermentation mixture \\
\hline Control & $17.5 \mathrm{~g}$ cow dung $+682.5 \mathrm{~mL}$ water \\
\hline $\begin{array}{c}\text { Raw mango pulp }(\mathrm{pH} \\
\text { adjusted) }\end{array}$ & $\begin{array}{l}17.5 \mathrm{~g} \text { cow dung }+332.5 \mathrm{~mL} \\
\text { mango pulp }+350 \mathrm{~mL} \text { water }\end{array}$ \\
\hline
\end{tabular}

Table 3: Composition of fermentation mixtures for biomethanation of mango pulp under varying concentrations of urea

\begin{tabular}{|c|c|}
\hline Experimental set-up & Fermentation mixture \\
\hline Control & $17.5 \mathrm{~g}$ cow dung $+682.5 \mathrm{~mL}$ water \\
\hline Raw mango pulp & $\begin{array}{c}17.5 \mathrm{~g} \text { cow dung }+332.5 \mathrm{~mL} \text { mango pulp }+ \\
350 \mathrm{~mL} \text { water }\end{array}$ \\
\hline $1 \%$ Urea added w/v & $\begin{array}{c}17.5 \mathrm{~g} \text { cow dung }+332.5 \mathrm{~mL} \text { mango pulp }+ \\
350 \mathrm{~mL} \text { water }\end{array}$ \\
\hline $2 \%$ Urea added w/v & $\begin{array}{c}17.5 \mathrm{~g} \text { cow dung }+332.5 \mathrm{~mL} \text { mango pulp }+ \\
350 \mathrm{~mL} \text { water }\end{array}$ \\
\hline $3 \%$ Urea added $\mathrm{w} / \mathrm{v}$ & $\begin{array}{c}17.5 \mathrm{~g} \text { cow dung }+332.5 \mathrm{~mL} \text { mango pulp }+ \\
350 \mathrm{~mL} \text { water }\end{array}$ \\
\hline $5 \%$ Urea added $\mathrm{w} / \mathrm{v}$ & $\begin{array}{c}17.5 \mathrm{~g} \text { cow dung }+332.5 \mathrm{~mL} \text { mango pulp }+ \\
350 \mathrm{~mL} \text { water }\end{array}$ \\
\hline $7 \%$ Urea added $\mathrm{w} / \mathrm{v}$ & $17.5 \mathrm{~g}$ cow dung $+332.5 \mathrm{~mL}$ mango pulp + \\
& $350 \mathrm{~mL}$ water \\
\hline
\end{tabular}

Table 4: Composition of fermentation mixture for biomethanation of mango pulp waste under different metal ions

\begin{tabular}{|c|c|}
\hline Experimental set-up & Fermentation mixture \\
\hline A (Negative Control) & $17.5 \mathrm{~g}$ cow dung $+682.5 \mathrm{~mL}$ water \\
\hline B (Positive Control) & $\begin{array}{c}17.5 \mathrm{~g} \text { cow dung }+332.5 \mathrm{~mL} \text { mango } \\
\text { pulp }+350 \mathrm{~mL} \text { water }\end{array}$ \\
\hline $\mathrm{FeCl}_{2}$ & $\begin{array}{c}17.5 \mathrm{~g} \text { cow dung }+332.5 \mathrm{~mL} \text { mango } \\
\text { pulp }+350 \mathrm{~mL} \text { water }+17.5 \mathrm{mg} \mathrm{FeCl} \\
(25 \mathrm{ppm})\end{array}$ \\
\hline $\mathrm{MgCl}_{2}$ & $\begin{array}{c}17.5 \mathrm{~g} \text { cow dung }+332.5 \mathrm{~mL} \text { mango } \\
\text { pulp }+350 \mathrm{~mL} \text { water }+17.5 \mathrm{mg} \mathrm{MgCl} \\
(25 \mathrm{ppm})\end{array}$ \\
\hline $\mathrm{CaCl}_{2}$ & $\begin{array}{c}17.5 \mathrm{~g} \text { cow dung }+332.5 \mathrm{~mL} \mathrm{mango} \\
\text { pulp }+350 \mathrm{~mL} \text { water }+17.5 \mathrm{mg} \mathrm{CaCl} l_{2} \\
(25 \mathrm{ppm})\end{array}$ \\
\hline $\mathrm{ZnCl}_{2}$ & $\begin{array}{c}17.5 \mathrm{~g} \text { cow dung }+332.5 \mathrm{~mL} \mathrm{mango} \\
\text { pulp }+350 \mathrm{~mL} \text { water }+17.5 \mathrm{mg} \mathrm{ZnCl} \mathrm{Zn}_{2} \\
(25 \mathrm{ppm})\end{array}$ \\
\hline
\end{tabular}




\section{International Journal of Science and Research (IJSR) \\ ISSN (Online): 2319-7064 \\ Index Copernicus Value (2013): 6.14 | Impact Factor (2015): 6.391}

Table 5: Composition of fermentation mixture for biomethanation of mango pulp waste under different combinations and concentrations of metal ions

\begin{tabular}{|c|c|}
\hline Experimental set-up & Fermentation mixture \\
\hline Negative Control & $17.5 \mathrm{~g}$ cow dung $+682.5 \mathrm{~mL}$ water \\
\hline Positive Control & $\begin{array}{l}17.5 \mathrm{~g} \text { cow dung }+332.5 \mathrm{~mL} \text { mango pulp }+ \\
350 \mathrm{~mL} \text { water }\end{array}$ \\
\hline A & $\begin{array}{c}17.5 \mathrm{~g} \text { cow dung }+332.5 \mathrm{~mL} \text { mango pulp }+ \\
350 \mathrm{~mL} \text { water }+3 \% \text { Urea }(\text { w/w })+25 \mathrm{ppm} \\
\mathrm{FeCl}_{2}+25 \mathrm{ppm} \mathrm{CaCl}_{2}+25 \mathrm{ppm} \mathrm{MgCl}_{2}+ \\
25 \mathrm{ppm} \mathrm{ZnCl}_{2}\end{array}$ \\
\hline B & $\begin{array}{c}\text { 17.5g cow dung }+332.5 \mathrm{~mL} \text { mango pulp }+ \\
350 \mathrm{~mL} \text { water }+3 \% \text { Urea }(\text { w/w })+25 \mathrm{ppm} \\
\mathrm{FeCl}_{2}+12.5 \mathrm{ppm} \mathrm{CaCl}_{2}+25 \mathrm{ppm} \mathrm{MgCl}_{2}+ \\
12.5 \mathrm{ppm} \mathrm{ZnCl}\end{array}$ \\
\hline $\mathrm{C}$ & $\begin{array}{c}\text { 17.5g cow dung }+332.5 \mathrm{~mL} \text { mango pulp }+ \\
350 \mathrm{~mL} \text { water }+3 \% \text { Urea }(\mathrm{w} / \mathrm{w})+25 \mathrm{ppm} \\
\mathrm{FeCl}_{2}+25 \mathrm{ppm} \mathrm{MgCl}_{2}\end{array}$ \\
\hline $\mathrm{D}$ & $\begin{array}{l}\text { 17.5g cow dung }+332.5 \mathrm{~mL} \text { mango pulp }+ \\
350 \mathrm{~mL} \text { water }+3 \% \text { Urea }(\mathrm{w} / \mathrm{w})+25 \mathrm{ppm} \\
\mathrm{FeCl}_{2}+25 \mathrm{ppm} \mathrm{CaCl}_{2}+25 \mathrm{ppm} \mathrm{MgCl}_{2}\end{array}$ \\
\hline
\end{tabular}

Table 6: Composition of fermentation mixture biomethanation of mango pulp waste under optimized conditions

\begin{tabular}{|c|c|}
\hline Experimental set-up & Fermentation mixture \\
\hline Negative Control & $17.5 \mathrm{~g}$ cow dung $+682.5 \mathrm{~mL}$ water \\
\hline Positive Control & $\begin{array}{c}17.5 \mathrm{~g} \text { cow dung }+332.5 \mathrm{~mL} \text { mango pulp + } \\
350 \mathrm{~mL} \text { water }+3 \% \text { Urea }\end{array}$ \\
\hline Test & $\begin{array}{c}17.5 \mathrm{~g} \text { cow dung }+332.5 \mathrm{~mL} \text { mango pulp }+ \\
\text { 350mL water }+3 \% \text { Urea }+25 \mathrm{ppm} \mathrm{FeCl}+ \\
\end{array}$ \\
$25 \mathrm{ppm} \mathrm{CaCl}+25 \mathrm{ppm} \mathrm{MgCl}_{2}$
\end{tabular}

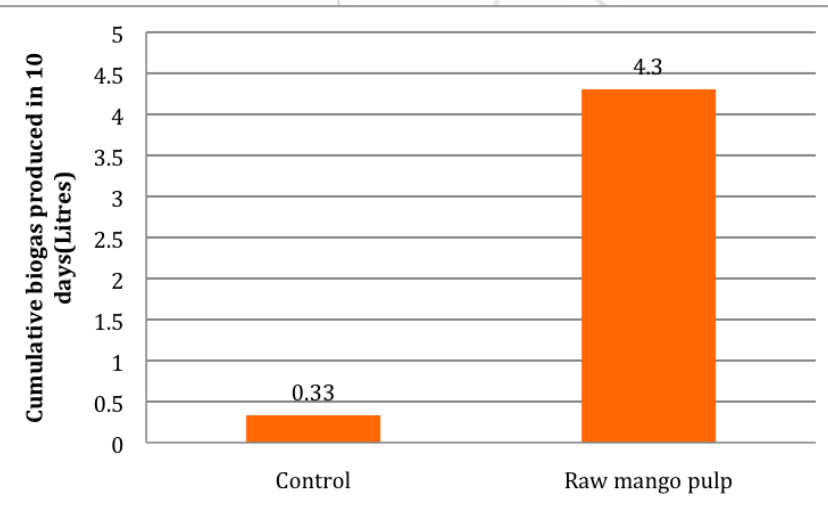

Figure 1: Biomethanation of mango pulp waste

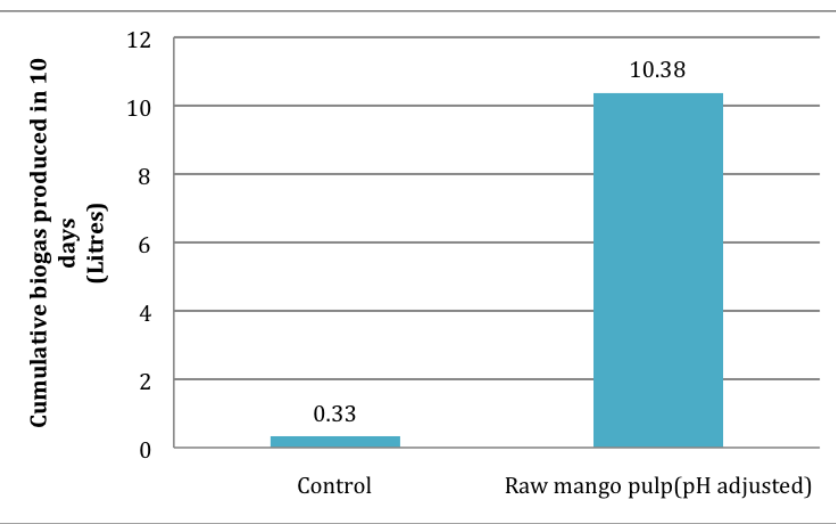

Figure 2: Biomethanation of $\mathrm{pH}$ adjusted mango pulp waste

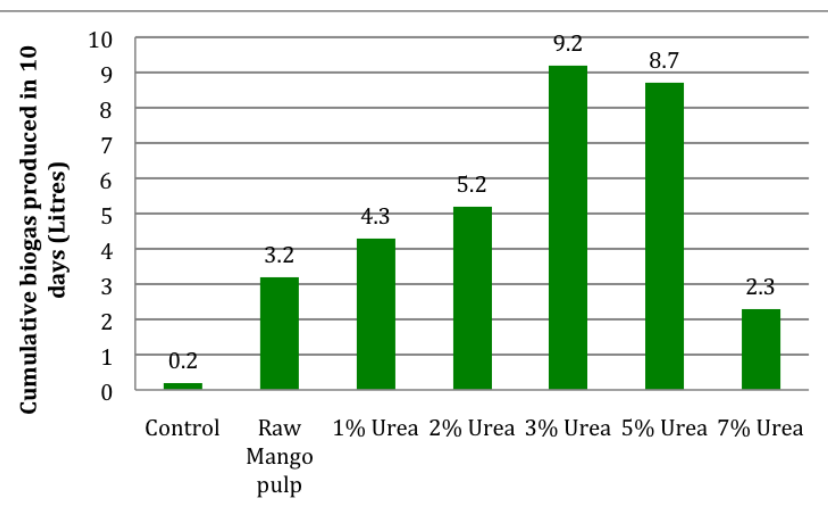

Figure 3: Biomethanation of mango pulp waste with varying concentrations of urea supplementation

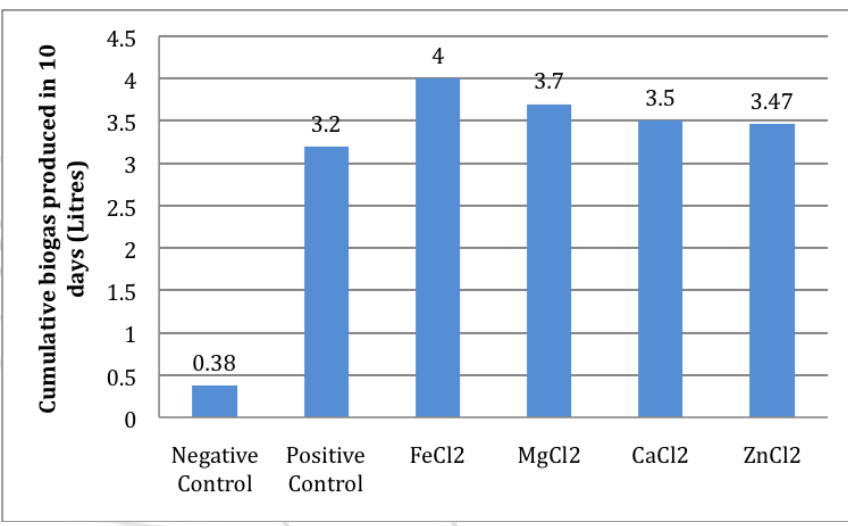

Figure 4: Impact of metal ions on Biomethanation of mango pulp waste

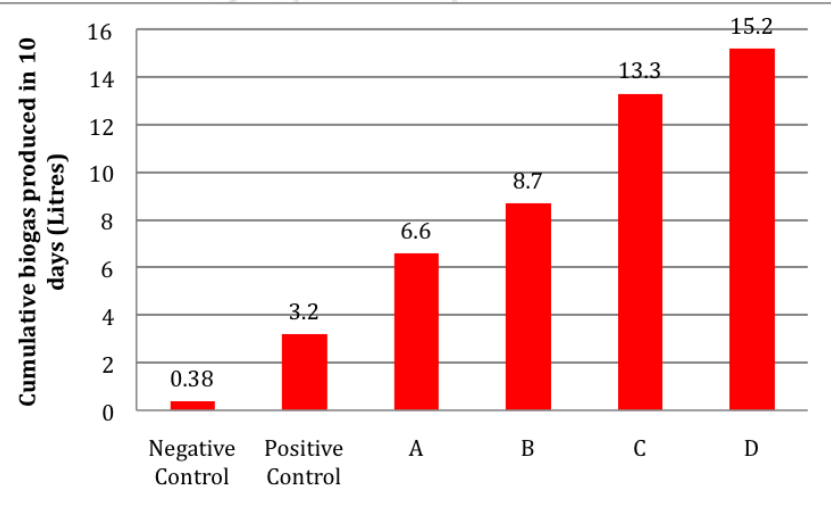

Figure 5: Effect of biomethanation of mango pulp waste under different combinations and concentrations of metal ions

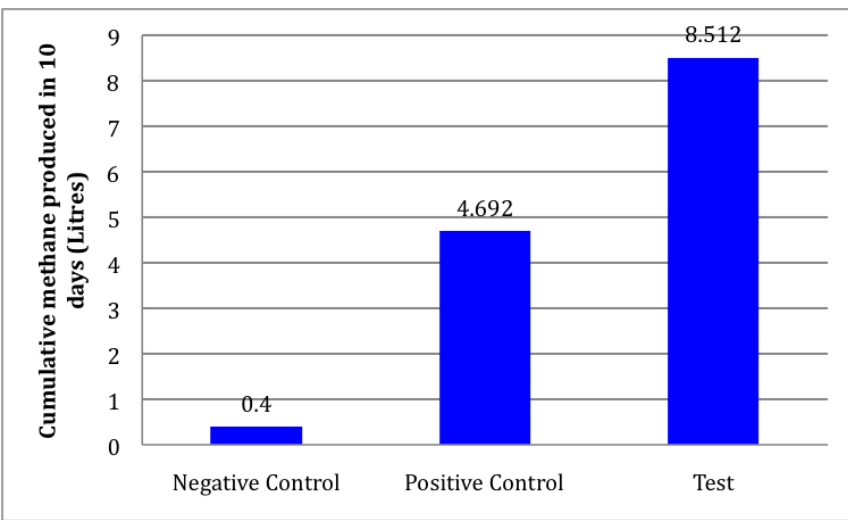

Figure 6: Effect of biomethanation of mango pulp waste under optimized conditions and quantification of methane 


\section{International Journal of Science and Research (IJSR) \\ ISSN (Online): 2319-7064}

Index Copernicus Value (2013): 6.14 | Impact Factor (2015): 6.391

\section{Conclusion}

The $\mathrm{pH}$ adjusted fermentation mixture gave more biogas than raw pulp. Addition of urea also increased the biogas production and metal ions of Iron, Magnesium, and Calcium have stimulatory effects at optimum concentration. Some metals are inhibitory at very low concentrations (e.g., $\mathrm{Zn}^{2+}$ ) whereas some are not inhibitory at high concentrations (e.g., $\mathrm{Fe}^{2+}$ ). Metal ions also increased the methane content of biogas. When combinations of various metal ions were used as additive, more biogas was produced than to any other individual metal ion containing substrate. Combined form of metal ion with urea also improved methane content of biogas. Monomer sugars present in mango pulp can be fermented for better biogas production Since mango is grown tropical climates, the possibility of bacterial contamination and fermentation is high, resulting in decayed and putrefied fruits, which leads to non-acceptance by customers. The damaged and rotten fruit from market as well as mango processing industry wastes can be used for the production of biogas, leading to cleaner environment and eco-friendly energy production for sustainable development.

\section{References}

[1] Rao, P. Venkateswara, et al. "Biogas generation potential by anaerobic digestion for sustainable energy development in India." Renewable and Sustainable Energy Reviews 14.7 (2010): 2086-2094.

[2] Ward, Alastair J., et al. "Optimisation of the anaerobic digestion of agricultural resources." Bioresource technology 99.17 (2008): 7928-7940.

[3] Álvarez, J. A., L. Otero, and J. M. Lema. "A methodology for optimising feed composition for anaerobic co-digestion of agro-industrial wastes." Bioresource Technology 101.4 (2010): 1153-1158.

[4] Murto, Marika, Lovisa Björnsson, and Bo Mattiasson. "Impact of food industrial waste on anaerobic codigestion of sewage sludge and pig manure." Journal of environmental management 70.2 (2004): 101-107.

[5] Di Maria, F., A. Sordi, and C. Micale. "Energy production from mechanical biological treatment and composting plants exploiting solid anaerobic digestion batch: an Italian case study." Energy Conversion and Management 56 (2012): 112-120.

[6] Tambone, Fulvia, et al. "Assessing amendment and fertilizing properties of digestates from anaerobic digestion through a comparative study with digested sludge and compost." Chemosphere 81.5 (2010): 577583.

[7] Abubaker, J., K. Risberg, and M. Pell. "Biogas residues as fertilisers-Effects on wheat growth and soil microbial activities." Applied Energy 99 (2012): 126134.

[8] Scano, Efisio Antonio, et al. "Biogas from anaerobic digestion of fruit and vegetable wastes: experimental results on pilot-scale and preliminary performance evaluation of a full-scale power plant." Energy Conversion and Management 77 (2014): 22-30.

[9] "Production/crops of mangoes including mangosteens and guavas for 2013". United Nations Food and
Agriculture Organization, Statistics Division. 2013 Retrieved 20 March 2016.

[10] Jahurul, M. H. A., et al. "Mango (Mangifera indica L.) by-products and their valuable components: A review." Food chemistry 183 (2015): 173-180.

[11] "USDA National Nutrient Database for Standard Reference, SR-28, Full Report (All Nutrients): 09176, Mangos, raw". National Agricultural Library. USDA. Retrieved 25 January 2016.

[12] Bouallagui, H., et al. "Bioreactor performance in anaerobic digestion of fruit and vegetable wastes." Process biochemistry 40.3 (2005): 989-995.

[13] Demirel, B., and P. Scherer. "Trace element requirements of agricultural biogas digesters during biological conversion of renewable biomass to methane." Biomass and Bioenergy 35.3 (2011): 992998.

\section{Author Profile}

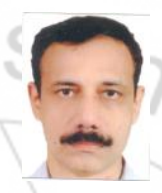

C.Gopinathan is currently working as Associate Professor at Department of Biotechnology, University of Calicut. He received the B.Sc in Botany, M.Sc in Life Sciences with specialization in Microbiology from University of Calicut and M.Tech in Biotechnology from Anna University, Chennai. He was former waste management consultant for Calicut Corporation, Kerala and is, at present consultant for Indian railways. He has handled various bioprocess scaled up projects and published \& presented his research works in leading Biotechnology conferences and International journals including World Biotechnology Congress. His specialization areas include fermentation technology in general and specifically biopesticide production, biogas production from agro waste, low cost mushroom production and high rate aerobic composting. 